\title{
Corrigendum
}

\section{Corrigendum to "Cytoprotective and Cytotoxic Effects of Rice Bran Extracts in Rat H9c2(2-1) Cardiomyocytes"}

\author{
Xian Wen Tan $\mathbb{D},{ }^{1,2}$ Mrinal Bhave, ${ }^{3}$ Alan Yean Yip Fong $\mathbb{D},{ }^{4,5}$ Eiji Matsuura, ${ }^{6,7}$ \\ Kazuko Kobayashi $\mathbb{D}^{6,}{ }^{6,7}$ Lian Hua Shen, ${ }^{6,7}$ and Siaw San Hwang $\mathbb{D}^{1,2}$ \\ ${ }^{1}$ Faculty of Engineering, Computing and Science, Swinburne University of Technology Sarawak Campus, Sarawak, Malaysia \\ ${ }^{2}$ Swinburne Sarawak Research Centre for Sustainable Technologies, Swinburne University of Technology Sarawak Campus, \\ Sarawak, Malaysia \\ ${ }^{3}$ Faculty of Science, Engineering and Technology, Swinburne University of Technology, Melbourne, VIC, Australia \\ ${ }^{4}$ Department of Cardiology, Sarawak General Hospital, Sarawak, Malaysia \\ ${ }^{5}$ Clinical Research Centre, Sarawak General Hospital, Sarawak, Malaysia \\ ${ }^{6}$ Collaborative Research Center (OMIC), Okayama University Graduate School of Medicine, Dentistry, and Pharmaceutical Sciences, \\ Okayama, Japan \\ ${ }^{7}$ Department of Cell Chemistry, Okayama University Graduate School of Medicine, Dentistry, and Pharmaceutical Sciences, \\ Okayama, Japan
}

Correspondence should be addressed to Siaw San Hwang; shwang@swinburne.edu.my

Received 19 November 2017; Accepted 28 November 2017; Published 22 January 2018

Copyright (C) 2018 Xian Wen Tan et al. This is an open access article distributed under the Creative Commons Attribution License, which permits unrestricted use, distribution, and reproduction in any medium, provided the original work is properly cited.

In the article titled "Cytoprotective and Cytotoxic Effects of Rice Bran Extracts in Rat H9c2(2-1) Cardiomyocytes" [1], errors in statistical analyses for inhibitory concentration $\left(\mathrm{IC}_{50}\right)$ have resulted in incorrect tabulations of data for both Tables 2 and 4 . The corrected versions of both tables are as below.

Accordingly, in the "Results" (Section 3.1), the text reading "Based on the results (Table 2), the $I C_{50}$ values of $R B E$ of $B J L N$ were in the range of 61.67 to $64.57 \mu \mathrm{g} / \mathrm{mL}$ over 24,48 , and 72 hours of incubation time." should be corrected to "Based on the results (Table 2), the $I C_{50}$ values of $R B E$ of $B J L N$ were in the range of 59.57 to $64.27 \mu g / m L$ over 24 , 48 , and 72 hours of incubation time.", and "Based on the results, the $I C_{50}$ values of MR219 RBE were in the range of 95.44 to $111.50 \mu \mathrm{g} / \mathrm{mL}$ over the three different incubation periods (Table 2)." should be corrected to "Based on the results, the $I C_{50}$ values of MR219 RBE were in the range of 95.56 to $111.40 \mu \mathrm{g} / \mathrm{mL}$ over the three different incubation periods (Table 2)."

In addition, in the "Results" (Section 3.3), the text reading "The positive effects were more distinctive with lower concentrations of RBE (BJLN: $25 \mu \mathrm{g} / \mathrm{mL}$; MR219: $50 \mu \mathrm{g} / \mathrm{mL}$ ) with observable increments in $\mathrm{IC}_{50}$ of $\mathrm{H}_{2} \mathrm{O}_{2}$ (BJLN: 645.65 $\mu$ M; MR219: 320.63 $\mu M$ ) (Table 4) when compared to negative control $(316.23 \mu \mathrm{M})$. When the two extracts were compared, BJLN $(25 \mu \mathrm{g} / \mathrm{mL})$ extract outran MR219 (50 $\mu \mathrm{g} /$ $m L$ ) extract in terms of efficacy with a significant increment in $\mathrm{IC}_{50}$ of $\mathrm{H}_{2} \mathrm{O}_{2}$ approximately twofold $(645.65 \mu \mathrm{M})$ versus $1.4 \%$ (in approximation) when compared to negative control $(316.23 \mu M)$." should be replaced with "The positive effects were more distinctive with lower concentrations of $R B E$ (BJLN: $25 \mu \mathrm{g} / \mathrm{mL}$; MR219: $50 \mu \mathrm{g} / \mathrm{mL}$ ) with observable increments in $\mathrm{IC}_{50}$ of $\mathrm{H}_{2} \mathrm{O}_{2}$ (BJLN: 597.20 $\mu \mathrm{M}$; MR219: $364.20 \mu \mathrm{M})$ (Table 4) when compared to negative control $(271.00 \mu M)$. When the two extracts were compared, BJLN $(25 \mu \mathrm{g} / \mathrm{mL})$ extract outran MR219 $(50 \mu \mathrm{g} / \mathrm{mL})$ extract in terms of efficacy with a significant increment in $I C_{50}$ of $\mathrm{H}_{2} \mathrm{O}_{2}$ by approximately 2-fold $(597.20 \mu \mathrm{M})$ versus 1.4-fold (in approximation) when compared to negative control $(271.00 \mu \mathrm{M})$. .", and the text reading "Significant decrements in the $\mathrm{IC}_{50}$ values of $\mathrm{H}_{2} \mathrm{O}_{2}$ were found for cell pretreated with $50 \mu \mathrm{g} / \mathrm{mL}$ BJLN $(92.90 \mu \mathrm{M})$ and $100 \mu \mathrm{g} / \mathrm{mL} \mathrm{MR219}$ 
TABLE 2: The relative inhibitory concentration $\left(\mathrm{IC}_{50}\right)$ of $\mathrm{RBE}$ of $\mathrm{BJLN}$ and MR219. Data presented as mean \pm standard deviation of three technical replicates $(n=3)$.

\begin{tabular}{|c|c|c|c|c|}
\hline & \multicolumn{2}{|c|}{ BJLN } & \multicolumn{2}{|c|}{ MR219 } \\
\hline & $\begin{array}{l}\log (\text { dose }) \\
(\mu \mathrm{g} / \mathrm{mL})\end{array}$ & $\begin{array}{c}\text { Dose } \\
(\mu \mathrm{g} / \mathrm{mL})\end{array}$ & $\begin{array}{c}\log (\text { dose }) \\
(\mu \mathrm{g} / \mathrm{mL})\end{array}$ & $\begin{array}{c}\text { Dose } \\
(\mu \mathrm{g} / \mathrm{mL})\end{array}$ \\
\hline $\begin{array}{l}\text { Day } 1 \\
\text { (24 hours) }\end{array}$ & $1.808 \pm 0.011$ & 64.27 & $1.980 \pm 0.013$ & 95.56 \\
\hline $\begin{array}{l}\text { Day } 2 \\
\text { (48 hours) }\end{array}$ & $1.775 \pm 0.002$ & 59.57 & $2.047 \pm 0.026$ & 111.40 \\
\hline $\begin{array}{l}\text { Day } 3 \\
\text { ( } 72 \text { hours) }\end{array}$ & $1.800 \pm 0.004$ & 63.10 & $2.033 \pm 0.029$ & 108.00 \\
\hline
\end{tabular}

TABle 4: Average $\mathrm{IC}_{50}$ of $\mathrm{H}_{2} \mathrm{O}_{2}$ for $\mathrm{H} 9 \mathrm{c} 2(2-1)$ cells. The $\mathrm{IC}_{50}$ value was determined from respective cell viability curves (Figure 5) via GraphPad Prism (GraphPad Software Inc., USA). Data represent mean \pm standard deviation of $3(n=3)$. * denotes significantly different from negative control treated with media $+1 \% \mathrm{EtOH}$ at $P \leq 0.05$. Graphical representations of data were depicted in Figure 5 .

\begin{tabular}{lrr}
\hline & \multicolumn{1}{c}{ Average $\mathrm{IC}_{50}$ of $\mathrm{H}_{2} \mathrm{O}_{2}(\mu \mathrm{M})$} & $\mathrm{H}_{2} \mathrm{O}_{2}$ \\
\hline Control sample & & \\
$\quad$ Negative control (media $+1 \% \mathrm{EtOH})$ & $2.433 \pm 0.040$ & \\
RBE & & \\
BJLN $(25 \mu \mathrm{g} / \mathrm{mL})$ & $2.776 \pm 0.028^{*}$ & 597.20 \\
BJLN $(50 \mu \mathrm{g} / \mathrm{mL})$ & $1.954 \pm 0.033^{*}$ & 89.95 \\
MR219 $(50 \mu \mathrm{g} / \mathrm{mL})$ & $2.561 \pm 0.035^{*}$ & 364.20 \\
MR219 $(100 \mu \mathrm{g} / \mathrm{mL})$ & $2.158 \pm 0.032^{*}$ & 143.90 \\
\hline
\end{tabular}

(171.79 $\mu \mathrm{M})$ extracts when compared to negative control $(316.23 \mu M)$ (Table 4). The higher concentrations of BJLN and MR219 extracts selected were near the range of $I C_{50}$ of both extracts $\left(I_{50}\right.$ of BJLN: $52.18 \mu \mathrm{g} / \mathrm{mL}$ to $73.09 \mu \mathrm{g} / \mathrm{mL}$; $I_{50}$ of MR219: $95.44 \mu \mathrm{g} / \mathrm{mL}$ to $\left.111.50 \mu \mathrm{g} / \mathrm{mL}\right)$." should be replaced with "Significant decrements in the $I C_{50}$ values of $\mathrm{H}_{2} \mathrm{O}_{2}$ were found for cell pretreated with $50 \mu \mathrm{g} / \mathrm{mL}$ BJLN $(89.95 \mu \mathrm{M})$ and $100 \mu \mathrm{g} / \mathrm{mL} \mathrm{MR} 219(143.90 \mu \mathrm{M})$ extracts when compared to negative control $(271.00 \mu M)$ (Table 4). The higher concentrations of BJLN and MR219 extracts selected were near the range of $I C_{50}$ of both extracts $\left(I C_{50}\right.$ of $B J L N$ :
$59.57 \mu \mathrm{g} / \mathrm{mL}$ to $64.27 \mu \mathrm{g} / \mathrm{mL}$; $I_{50}$ of $M R 219: 95.56 \mu \mathrm{g} / \mathrm{mL}$ to $111.40 \mu \mathrm{g} / \mathrm{mL})$."

An incorrect version of Figure 3 with missing graphical elements was published. The corrected version of Figure 3 with the inclusion of graphical elements is as shown below.

Accordingly, Figure 5(b) presented in the original manuscript was also the incorrect version. The fourth datum point for MR219 $(50 \mu \mathrm{g} / \mathrm{mL})$ (grey dotted line) was incorrectly plotted. The correct version of the figure is as shown below with the corrected fourth datum point for MR219 $(50 \mu \mathrm{g} / \mathrm{mL})$ (grey dotted line).
Total phenolic content

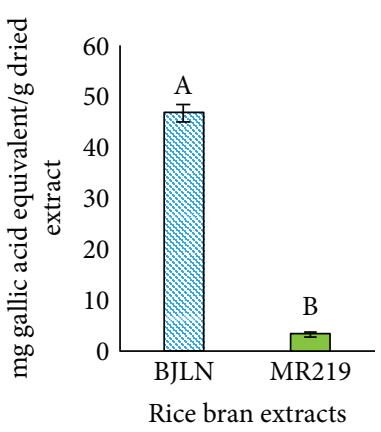

(a)

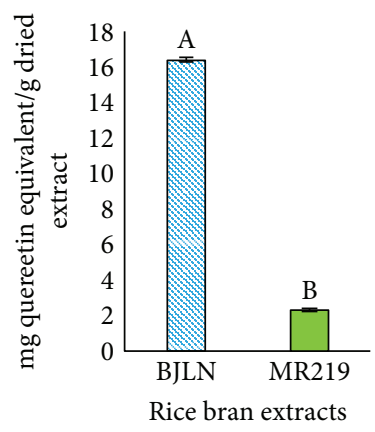

(b)
Total anthocyanin content

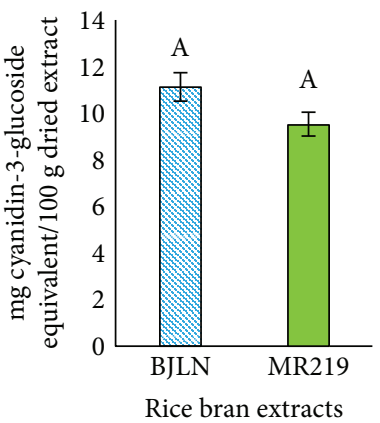

(c)
Total $\gamma$-oryzanol content

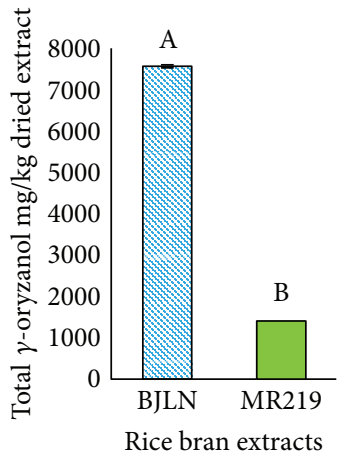

(d)

Figure 3: Continued. 
$\delta$-Tocotrienols (T3)

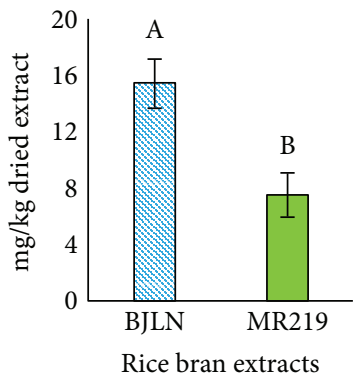

(e)

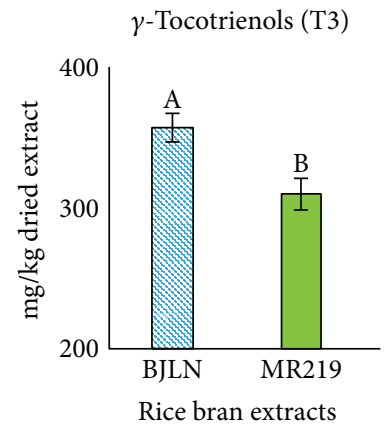

(f)

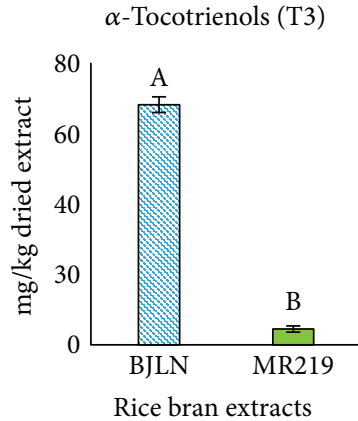

(g)
Total tocotrienol (T3) content

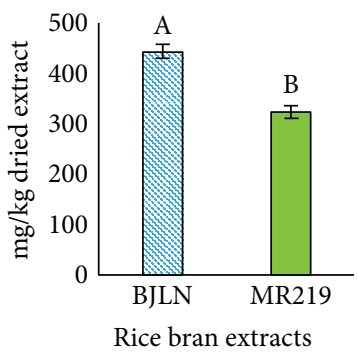

(h)

Figure 3: Total contents of selected bioactive compounds in the RBE. Different letters on a bar represent significant differences at $P \leq 0.05$ (Tukey's test).

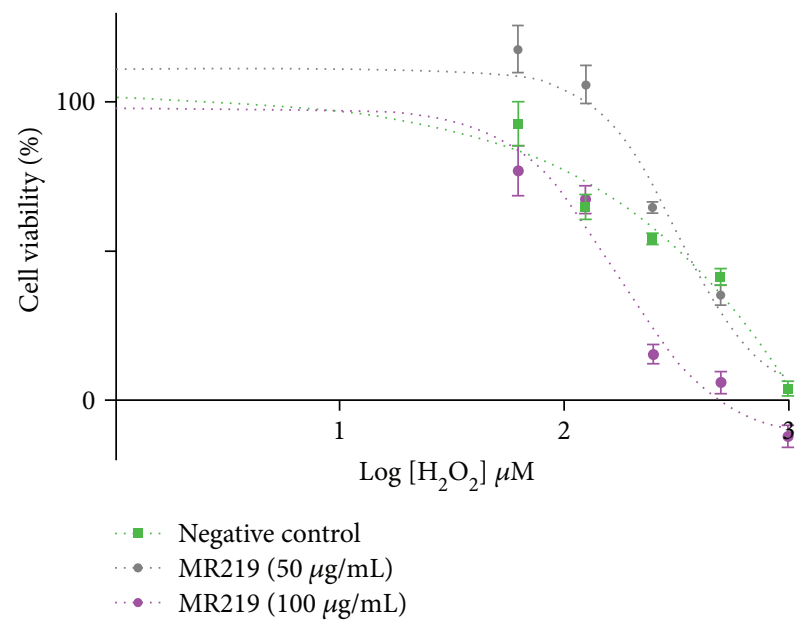

(b) $\mathrm{RBE}(\mathrm{MR} 219)+\mathrm{H}_{2} \mathrm{O}_{2}$ induction

FIgURE 5: Effects of $\mathrm{H}_{2} \mathrm{O}_{2}$ inductions on cell viabilities of $\mathrm{H} 9 \mathrm{c} 2(2-1)$ cardiomyocytes pretreated with different concentrations of (a) BJLN $\mathrm{RBE}(25 \mu \mathrm{g} / \mathrm{mL}$ and $50 \mu \mathrm{g} / \mathrm{mL})$ and (b) MR219 RBE $(50 \mu \mathrm{g} / \mathrm{mL}$ and $100 \mu \mathrm{g} / \mathrm{mL})$.

\section{References}

[1] X. W. Tan, M. Bhave, A. Y. Y. Fong et al., "Cytoprotective and cytotoxic effects of rice bran extracts in rat H9c2(2-1) cardiomyocytes," Oxidative Medicine and Cellular Longevity, vol. 2016, Article ID 6943053, 12 pages, 2016. 


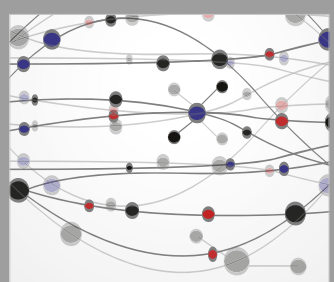

The Scientific World Journal
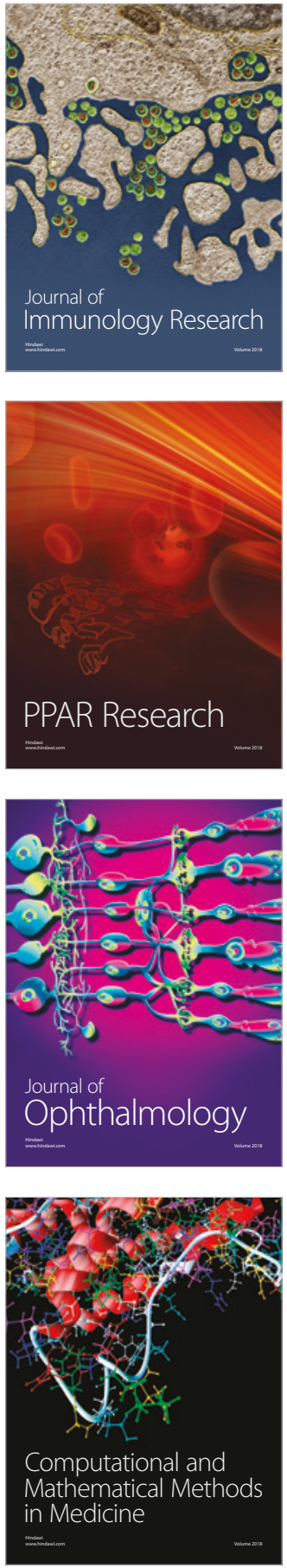

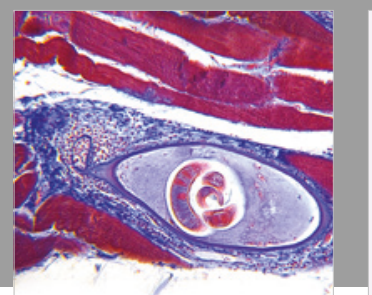

Gastroenterology Research and Practice

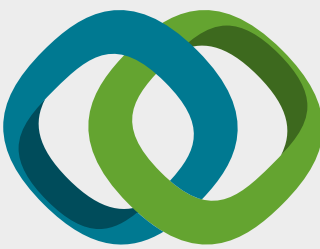

\section{Hindawi}

Submit your manuscripts at

www.hindawi.com
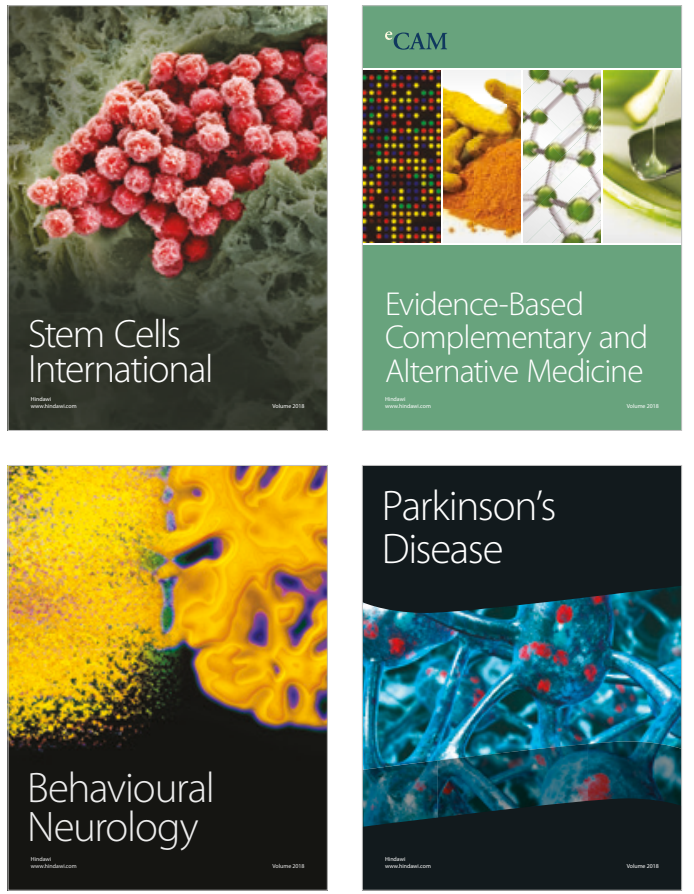

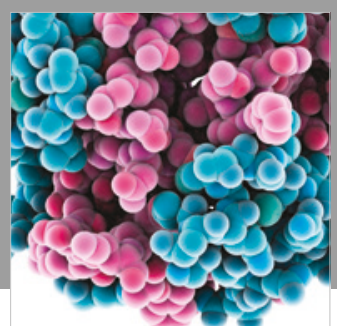

ournal of

Diabetes Research

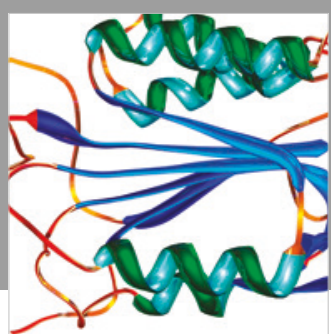

Disease Markers
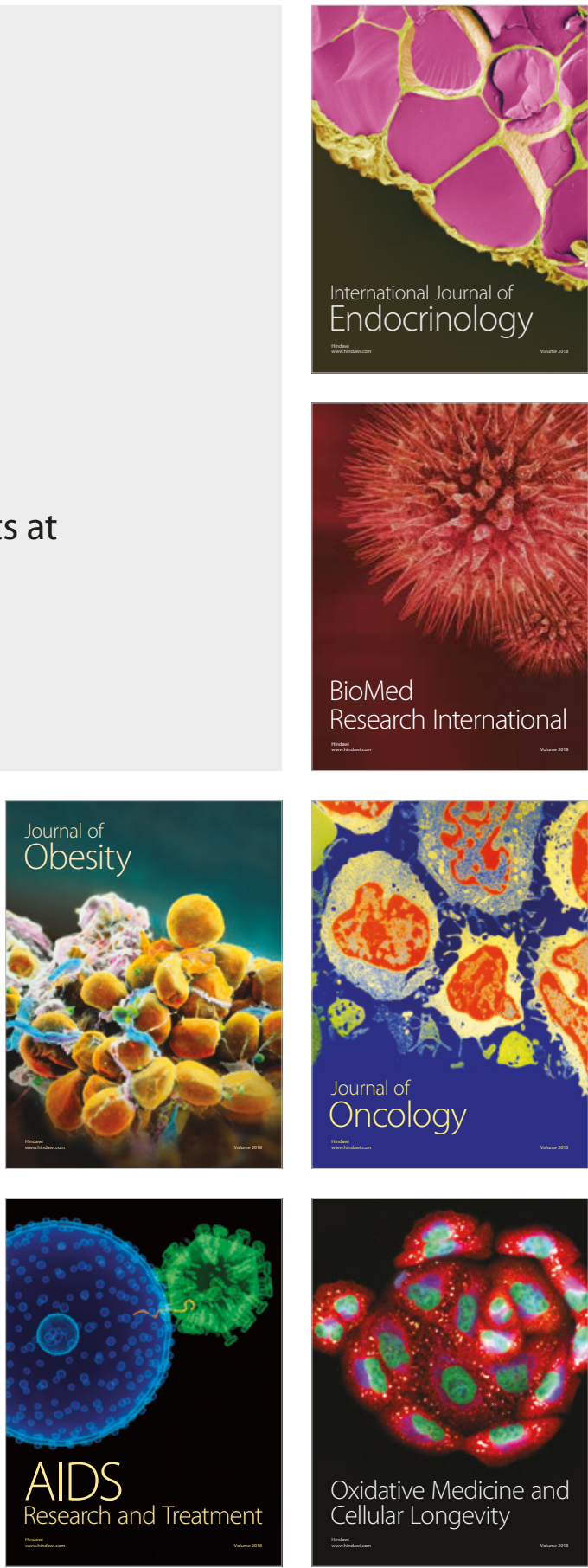